\title{
CYTOGENETIC STUDIES OF TWO FRESHWATER SCIAENIDS OF THE GENUS Plagioscion (PERCIFORMES, SCIAENIDAE) FROM THE CENTRAL AMAZON
}

\author{
Eliana Feldberg ${ }^{1}$, Jorge Ivan Rebelo Porto ${ }^{1}$, Elen Bethlen Pedraça dos Santos ${ }^{2}$ and Francisco Carlos Souza Valentim ${ }^{2}$
}

\begin{abstract}
Cytogenetic characterization of two freshwater sciaenid species from the genus Plagioscion ( $P$. squamosissimus and $P$ lagioscion sp.) was obtained for the first time. Giemsa staining, Ag-NOR and C-banding revealed that both species presented $2 \mathrm{n}=48$ chromosomes (almost all acrocentric). Single NORs and heterochromatin were found mainly at the pericentromeric position. Karyotypic formulae and NOR location proved to be valuable in showing both interspecific and intraspecific differences. All chromosomes were acrocentric in $P$. squamosissimus. NORs were located at proximal positions on the long arms of the last chromosome pair of the complement, and were heteromorphic due to size differences. Such heteromorphic NORs seem to be associated with each population sampled. Plagioscion sp. presented two cytotypes: cytotype a (2M + 46A) and cytotype b $(48 \mathrm{~A})$. In both cytotypes, NOR-bearing chromosomes were located at the proximal position on the long arms of the first chromosome pair of the complement. However, NOR-bearing chromosomes were metacentric in cytotype a and acrocentric in cytotype b.
\end{abstract}

\section{INTRODUCTION}

The percoid family Sciaenidae is a very important world fish resource, and includes about 70 genera and 270 species (Nelson, 1994). In South America, sciaenids occur in marine, brackish, and freshwater habitats. True freshwater sciaenids encompass three genera: Plagioscion, Pachypops and Pachyurus. Plagioscion is broadly distributed in South America, occurring from Paraguay (Ringuelet et al., 1967) to Venezuela (Mago-Leccia, 1970; Dahl, 1971). Compared to other sciaenid genera, Plagioscion is the most common and important fish resource in the Amazon basin (Santos et al., 1984). Although Plagioscion is reported to be found mainly in the river channel, it also occurs in the marginal lakes of the floodplains. Plagioscion is also considered to be one of the largest predatory forms in mid- and surface waters of the Amazonian Rivers, feeding exclusively on fish and shrimp (Goulding, 1979, 1980). Spawning seems to occur during the whole year, without a well-defined reproductive peak (Santos et al., 1984 ). Soares (1978) made a taxonomic revision of sciaenid fishes from the Amazon basin, in which she reported four Plagioscion species in the Amazon: $P$. auratus, $P$. squamosissimus, $P$. surinamensis and a new species described as $P$. montei. However, $P$. montei cannot be considered a taxonomically valid name, because Soares' thesis has not been published.

\footnotetext{
${ }^{1}$ Coordenação de Pesquisas em Biologia Aquática, Instituto Nacional de Pesquisas da Amazônia, Alameda Cosme Ferreira, 1756, 69083-000, Manaus, AM, Brasil. Send correspondence to E.F. Fax: +55-92-643-3292/ 643-3095. E-mail: feldberg@inpa.gov.br/jirporto@inpa.gov.br

${ }^{2}$ Programa de Pós-Graduação Genética e Evolução, Universidade do Amazonas, Instituto de Biociências, Departamento de Biologia, Estrada do Campus Universitário, 69077-000, Manaus, AM, Brasil.
}

To date, 21 sciaenids have been studied cytogenetically. However, freshwater sciaenid species have never been analyzed. LeGrande and Fitzsimons (1988) summarized chromosomal information about 11 marine sciaenid species included in nine genera. However, this report lacked the records of two South American sciaenids studied by Gomes et al. (1983a,b) and Pereira et al. (1988), as well as three Indian sciaenids studied by Chakraborty (1986) and Tripathi and Das (1988). Since then, five other marine sciaenids have been studied (Chakraborty and Kagwade, 1989; Khuda-Bukhsh and Nayak, 1990; Wang et al., 1994; Yu et al., 1996). Most sciaenids have a diploid number of $2 n=48$ chromosomes and are almost exclusively acrocentric. This paper provides the first description of karyotypes for two freshwater sciaenid species: Plagioscion squamosissimus and Plagioscion sp. (Soares' P. montei), both of which occur in the central Amazon basin.

\section{MATERIAL AND METHODS}

Forty specimens of Plagioscion squamosissimus were collected from three different sites in the Amazon basin (Tefé River: six males; Catalão Lake: 17 males, eight females and five unsexed individuals, and Pitinga River: one male and three females). Seventeen specimens of Plagioscion sp. (nine males and eight females) were collected at Catalão Lake in the confluence of the Negro and Solimões Rivers (Figure 1). Voucher specimens were deposited at the Instituto Nacional de Pesquisas da Amazônia. Metaphases were obtained after yeast infection using the technique of Lozano et al. (1988). Anterior kidney cell suspensions were obtained after two different treatments with colchicine: in vivo (Bertollo et al., 1978) and in vitro (Moreira Filho and Bertollo, 1990). In vivo treatment consisted of injecting the fish with $0.025 \%$ colchicine $(1 \mathrm{ml} /$ $100 \mathrm{~g}$ body weight) and letting the animal retain this alka- 
loid for 40-60 min, whereas in the in vitro treatment, kidney tissue was minced in $10 \mathrm{ml}$ of $0.075 \mathrm{M} \mathrm{KCl}$, incubated at $37^{\circ} \mathrm{C}$ for $15 \mathrm{~min}$, and then $50 \mu \mathrm{l}$ of $0.017 \%$ colchicine was added. The sample was then incubated for an additional $15 \mathrm{~min}$. Cell suspensions obtained in both treatments were fixed three times in fresh methanol-acetic acid (3:1) fixative. These suspensions were subsequently dropped on clean warm slides $\left(60^{\circ} \mathrm{C}\right)$ and stained by $5 \%$ phosphate Giemsa solution. Nucleolar organizer regions (NORs) were visualized after silver staining following Howell and Black (1980), and the constitutive heterochromatin was detected following Sumner (1972). Chromosome morphology was determined on the basis of arm ratios, as proposed by Levan et al. (1964). Secondary constrictions, however, were not considered in the measurement.

\section{RESULTS}

Different karyotypes were observed in the two species studied: Plagioscion squamosissimus presented 48 acrocentric chromosomes (arm number $(\mathrm{AN})=48$ ) including a single pair of NOR-bearing chromosomes (Figure
2A). NORs of different size, located at the proximal position on the long arms, were noted in the homologous chromosomes and were assigned to the 24th chromosome pair. One of the homologous chromosomes presented a stronger affinity to Ag-NOR staining. Specimens from the Tefé population (Figures 1 and 2B 1) presented less variable NOR size differences. Specimens from the Pitinga population (Figures 1 and 2B 3) presented the greatest size heteromorphism, while the Catalão population seemed to be intermediate (Figures 1 and 2B 2).

Plagioscion sp. presented two cytotypes. Cytotype a $(\mathrm{n}=15)$ is characterized by two metacentric and 46 acrocentric chromosomes (AN $=50)$, while cytotype $\mathbf{b}(n=2)$ is characterized by 48 acrocentric chromosomes $(\mathrm{AN}=48)$. In both cytotypes, NORs are located at the proximal position on the long arms of the first chromosome pair of the complement. NOR-bearing chromosomes are distinct in each cytotype, since the first pair is metacentric in cytotype a (Figure 3A) whereas it is acrocentric in cytotype b (Figure 3B). Heteromorphic NORs due to size differences within the same pair were observed in both cytotypes, but were not as conspicuous as those observed in P. squamosissimus.

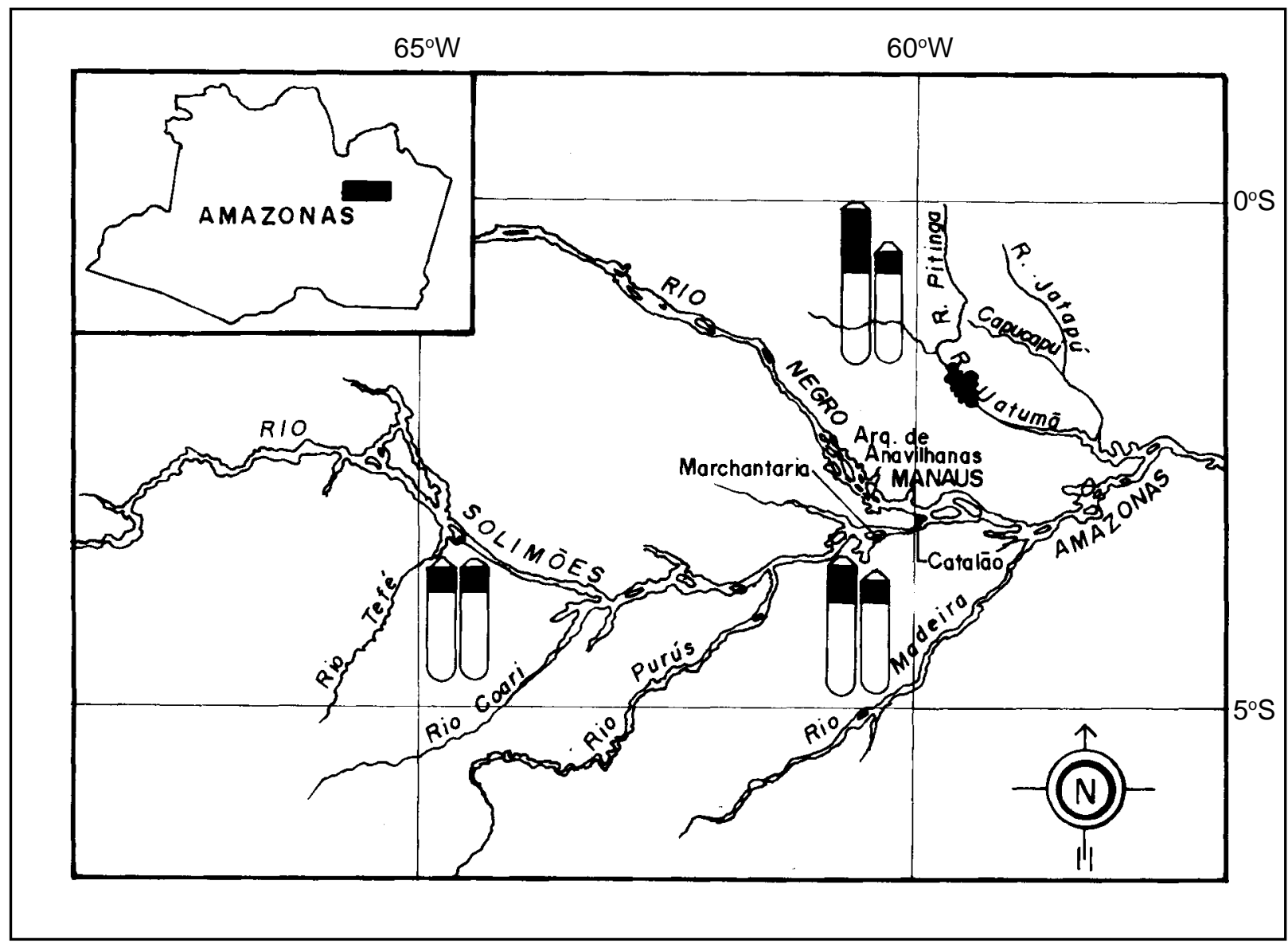

$1: 6.000 .000$

Figure 1 - Map of central Amazon showing capture localities and idiograms of NOR phenotypes of Plagioscion squamosissimus. 


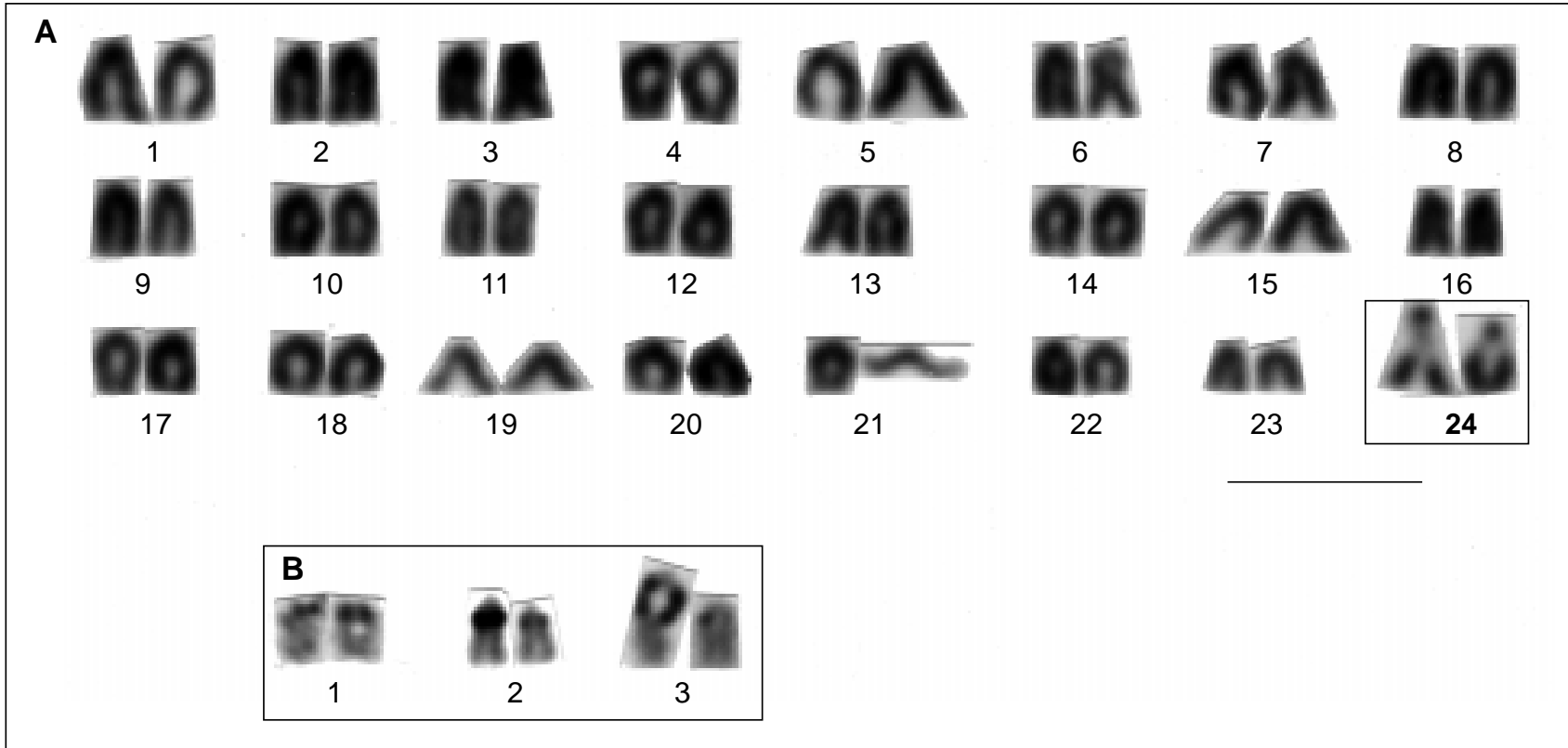

Figure 2 - Karyotype of Plagioscion squamosissimus. NOR-bearing chromosomes appear in the square inset as evidenced by Giemsa-staining (A) and silver nitrate (B). B1, B2, and B3 correspond to NOR heteromorphisms detected in Tefé River, Catalão Lake, and Pitinga River, respectively. Scale bar corresponds to $5 \mu \mathrm{m}$.

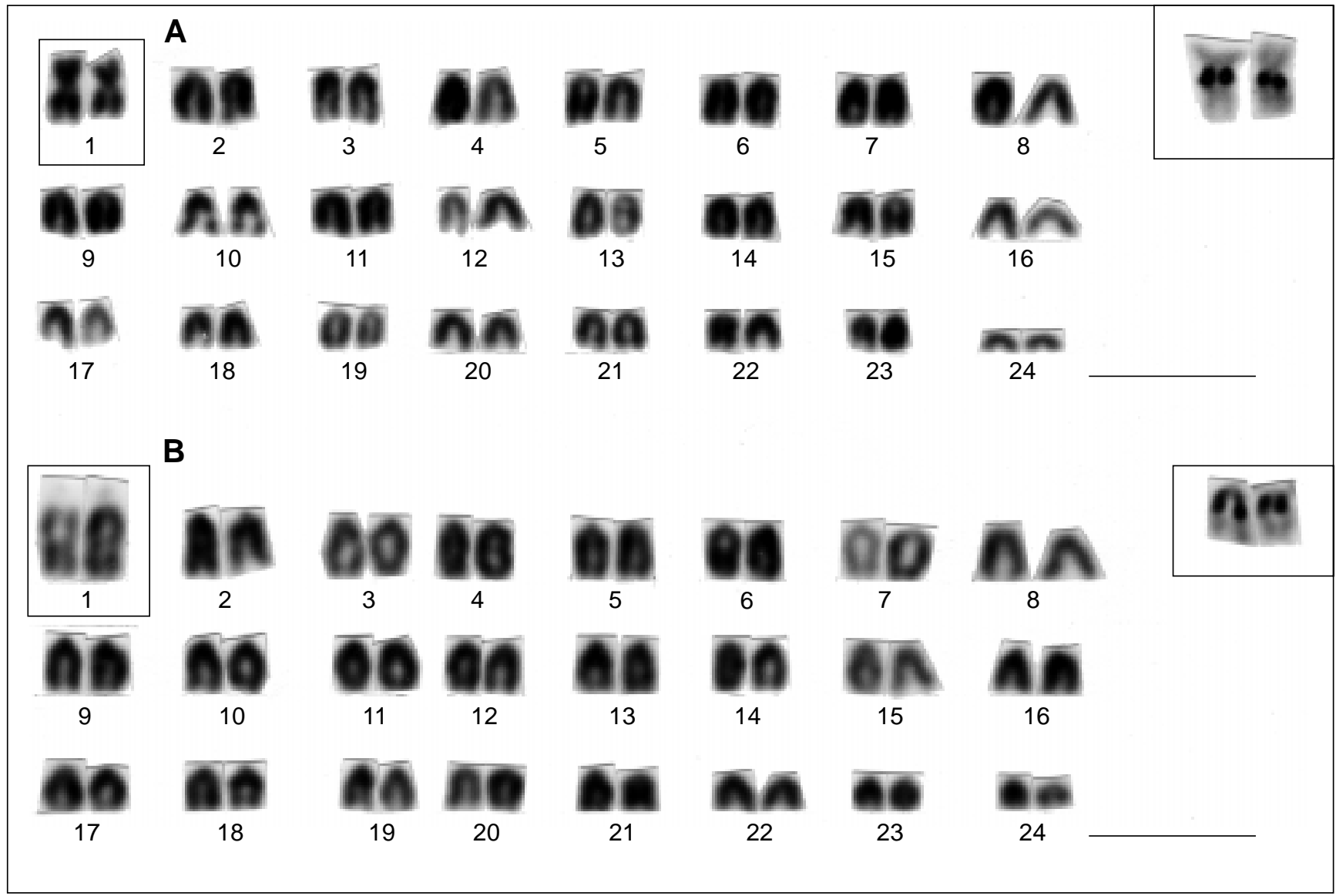

Figure 3 - Karyotype of Plagioscion sp. A) Cytotype a and B) cytotype b. NOR-bearing chromosomes appear in the square inset. Scale bar corresponds to $5 \mu$ m. 

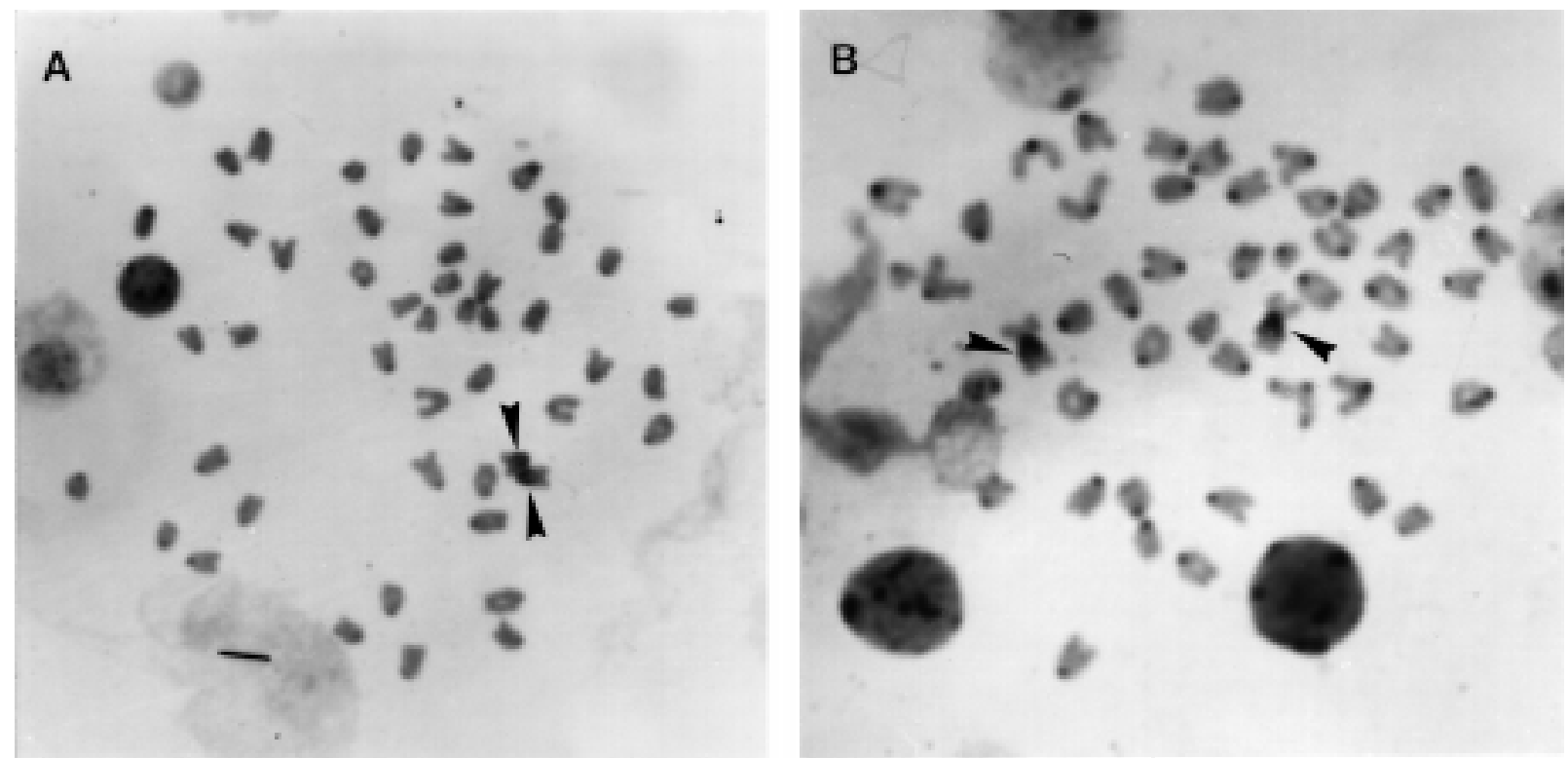

Figure 4 - Constitutive heterochromatin of (A) Plagioscion squamosissimus and (B) Plagioscion sp. (cytotype a). Arrowheads indicate NOR-bearing chromosomes.

Constitutive heterochromatin patterns obtained for P. squamosissimus and Plagioscion sp. (only cytotype a) show that heterochromatin blocks are located exclusively in the pericentromeric region of all chromosomes, except in the NOR region, where a conspicuous heterochromatic block was observed (Figure 4).

\section{DISCUSSION}

Of 23 nominal sciaenid species examined cytogenetically (including the present study), two did not have $2 \mathrm{n}=48$ chromosomes, and three did not have $\mathrm{AN}=48$ (exclusively acrocentric structure). NOR data on sciaenids had been reported previously only in a preliminary manner (Brum et al., 1996). However, secondary constrictions had been reported in some sciaenid species. One may speculate that NOR-bearing chromosomes are located in a proximal position on the long arms of the largest acrocentric pair of Micropogonias furnieri and Menticirrhus americanus (Gomes et al., 1983a,b) and on the third acrocentric pair of Nibea albiflora (Yu et al., 1996) because secondary constrictions and NORs are usually coincident.

Two of the three karyotypes described here for the freshwater genus Plagioscion have retained the hypothetical plesiomorphic sciaenid (and perciform) karyotype, i.e., $2 \mathrm{n}=48$ acrocentric chromosomes; apparently no major chromosomal changes have been related to this genus' adaptation process from marine to freshwater environments during chromosomal evolution. Chromosomal differences detected in the first chromosome pair of Plagioscion sp. led to the recognition of two cytotypes: cytotype a, the most common one, with one metacentric pair herein considered to be the chromosomal marker and cytotype $\mathbf{b}$, with only acrocentric chromosomes (Figure 3 ). In both cytotypes, the NOR-bearing chromosomes correspond to the largest pair, and the relative chromosomal length did not differ significantly among them. Thus, we suggest that they are the homologous chromosome pair. The different morphology of NOR-bearing chromosomes seems to be the only distinction between the two cytotypes, and was probably induced by pericentric inversion.

Both $2 n=48$ and AN $=48$ seem to be the plesiomorphic chromosomal state. This means that cytotype a should derive from cytotype $\mathbf{b}$, thus leading to two hypothesis: either the pericentric inversion is a recent karyoevolutionary process, since cytotype b might correspond to a few individuals in the population that have retained the ancestral chromosomal state, or cytotype a and cytotype b may correspond to two cryptic species (same morphology and geographic distribution, but genetically distinct). To test the first hypothesis, additional sampling (including other sites in the Amazon) is necessary to check if cytotype a is not yet fixed in the whole population. To test the second hypothesis, molecular biology or other genetic tools must be employed in order to look for other differences. Except for Bairdiella chrysoura (Gregory et al., 1980; Le Grande and Fitzsimons, 1988) and M. furnieri (Brum et al., 1996), different karyotypic formulae in the same nominal species is an uncommon feature in the Sciaenidae family.

In $P$. squamosissimus, chromosomal differences detected also involved NOR-bearing chromosomes (Figure 2B). These chromosomes were considered the main chromosomal marker among the populations of $P$. squamosissimus studied, since heteromorphic NORs were observed in each population sampled (Figure 1). NOR size 
differences, as those observed in P. squamosissimus, have been reported in the marine sciaenid M. furnieri (Brum et al., 1996) and a few other perciforms (for example, Rossi et al., 1997). Differential transcriptional activity of rDNA genes is commonly evoked to explain such heteromorphic NORs. However, rather than only transcriptional activity, an alternative explanation is that $P$. squamosissimus are carriers of unequal crossing-over between homologous NOR-bearing chromosomes, which now are fixed in each population. Therefore, a genetic basis might rule such population differentiation. Migratory patterns of $P$. squamosissimus are not well known, but seasonal migrations have been reported (Goulding, 1980). In the Amazon basin, a large and open water system in which most of the commercial fish species are widely distributed (including Plagioscion species), it is extremely difficult to determine how many distinct populations or stocks of a given species are present throughout the area (Goulding et al., 1996). Heteromorphic NORs detected in P. squamosissimus suggest that such phenotypes may be valuable for genetical recognition of different populations in the central Amazon. Variations in copy number and site distribution of rDNA clusters/NORs have been described extensively in fish species, and have allowed the characterization of intraspecific stocks or populations in some fish groups (Phyllips et al., 1988; Castro et al., 1996), but to our knowledge the present study is the first to show this situation in Neotropical Perciformes.

Concerning C-banding patterns, no major differences were observed between or within Plagioscion species, since only small heterochromatin blocks were detected in pericentromeric regions (Figure 4). Low amounts of constitutive heterochromatin, mostly confined to pericentromeric regions, have also been detected in marine sciaenids M. furnieri (Gomes et al., 1983a; Brum et al., 1996), M. americanus (Gomes et al., 1983b), and B. chrysoura (Gregory et al., 1980). C-banding data strongly suggest that heterochromatinization processes did not evolve during sciaenid chromosomal evolution, because no intercalar or telomeric $\mathrm{C}$-bands could be detected. This also indicates a highly conserved karyotype with minor restructuring. However, both $P$. squamosissimus and Plagioscion sp. (cytotype a) showed an association of Cpositive band and NOR size, as is usually demonstrated by Ag-NOR and C-banding analyses.

Although only a few sciaenid species were karyologically studied with banding techniques, these data suggest that, in the evolution of this group, chromosome changes first occurred in NOR location or NOR size, or in both. This means that ribosomal genes may play an important role in the karyotypic plasticity of this group. Further analyses using in situ hybridization, fluorochromes, and endonucleases will allow a better understanding of the molecular structure of Plagioscion's chromosomes especially in the localization of rDNA clusters and in the identification of different heterochromatin classes.

\section{ACKNOWLEDGMENTS}

We thank Drs. Orlando Moreira Filho, José Gomes, Aylton Teixeira and Elizabeth Leão for helpful comments on an earlier version of the manuscript. This work was supported by CNPq (grants to E. Feldberg and J.I.R. Porto), and INPA (PPI3270 and 3370). E.B.P. Santos and F.C.S. Valentim are recipients of CNPq fellowships.

\section{RESUMO}

Foram estudados, pela primeira vez, os cariótipos de duas espécies de sciaenídeos de água doce, pertencentes ao gênero Plagioscion (P. squamosissimus e Plagioscion sp.), através de técnicas de coloração convencional (Giemsa), NOR e banda C. Todos os indivíduos apresentaram $2 \mathrm{n}=48$, NOR simples e banda C preferencialmente pericentromérica. Porém, a fórmula cariotípica e a localização das NORs permitiram-nos evidenciar diferenças inter- e intra-específicas. Em P. squamosissimus, as NORs estão localizadas em posição proximal nos braços longos do último par do complemento e são heteromórficas em relação ao tamanho das marcações. Aparentemente, esse heteromorfismo de NOR está associado com diferenças populacionais. Por outro lado, Plagioscion sp. apresentou dois citótipos. O citótipo a é caracterizado por 2 cromossomos metacêntricos e 46 acrocêntricos, enquanto o citótipo b é caracterizado por 48 cromossomos acrocêntricos. Em ambos citótipos, as NORs estão localizadas em posição proximal nos braços longos do primeiro par de cromossomos do complemento. Porém, no citótipo a essas marcações localizam-se em um par de cromossomos metacêntricos, enquanto no citótipo b em um acrocêntrico.

\section{REFERENCES}

Bertollo, L.A.C., Takahashi, C.S. and Moreira Filho, O. (1978). Cytotaxonomic considerations on Hoplias lacerdae (Pisces, Erythrinidae). Rev. Bras. Genét. I: 103-120.

Brum, M.J.I., Corrêa, M.M.O., Purcell, C.A., Ribeiro, V.P. and Muratori, R.S. (1996). Análise cromossômica em Xenomelaniris brasiliensis (Atherinidae), Micropogonias furnieri (Sciaenidae) e Bathygobius soporator (Gobiidae) do litoral do Estado do Rio de Janeiro. VI Simpósio de Citogenética Evolutiva e Aplicada de Peixes Neotropicais: 101 (Abstract).

Castro, J., Viñas, A., Sánchez, L. and Martínez, P. (1996). Characterization of an atypical NOR site polymorphism in brown trout (Salmo trutta) with Ag- and $\mathrm{CMA}_{3}$-staining, and fluorescent in situ hybridization. Heredity 75: 234-239.

Chakraborty, S.K. (1986). Chromosome counts of Nibea semiluctuosa and Johnius belangerii (Pisces: Sciaenidae). Indian J. Fish. 33: 115-118.

Chakraborty, S.K. and Kagwade, P.V. (1989). Somatic chromosomes of two marine teleosts. In: Fish Genetics in India: Proceedings of the Symposium on Conservation and Management of Fish Genetic Resources of India (Das, P. and Jhingran, A.G., eds.). Today and Tomorrow's Printers and Publishers, New Delhi, India, pp. 63-68.

Dahl, G. (1971). Los Peces del Norte de Colombia. Ministerio de Agricultura, Inderena, Bogota.

Gomes, V., Vazzoler, A.E. de M. and Phan, V.N. (1983a). Estudos cariotípicos de peixes da família Sciaenidae (Teleostei, Perciformes) da região de Cananéia, SP, Brasil. 1. Sobre o cariótipo de Micropogonias furnieri (Desmarest, 1823). Bol. Inst. Oceanogr. 32: 137142.

Gomes, V., Vazzoler, A.E. de M. and Phan, V.N. (1983b). Estudos cariotípicos de peixes da família Sciaenidae (Teleostei, Perciformes) da região de Cananéia, SP, Brasil. 2. Sobre o cariótipo de Menticirrhus 
americanus (Linnaeus, 1758). Bol. Inst. Oceanogr. 32: 187-191.

Goulding, M. (1979). Ecologia da Pesca do Rio Madeira. INPA, Manaus. Goulding, M. (1980). The Fishes and the Forest: Explorations in Amazonian Natural History. University of California Press, Berkeley.

Goulding, M., Smith, N.J.H. and Mahar, D.J. (1996). Floods of Fortune: Ecology and Economy along the Amazon. Columbia University Press, New York.

Gregory, P.E., Howard-Peebles, P.N., Ellender, R.D. and Martin, B.J. (1980). C-banding of chromosomes from three established marine fish cell lines. Copeia 4: 545-547.

Howell, W.M. and Black, D.A. (1980). Controlled silver staining of nucleolus organizer regions with a protective colloidal developer: a 1-step method. Experientia 36: 1014-1015.

Khuda-Bukhsh, A.R. and Nayak, K. (1990). Karyotypic studies in six species of brackish water fishes from India. Kromosomo 58: 1955-1960.

LeGrande, W.H. and Fitzsimons, J.M. (1988). Chromosome numbers of some Gulf Coast sciaenid fishes. Copeia 2: 491-493.

Levan, A., Fredga, K. and Sandberg, A.A. (1964). Nomenclature for centromeric position on chromosomes. Hereditas 52: 201-220.

Lozano, R., Rejon, C.R. and Rejon, M.R. (1988). A method for increasing the number of mitoses available for cytogenetic analysis in rainbow trout. Stain Technol. 63: 335-338.

Mago-Leccia, F. (1970). Lista de los Peces de Venezuela. Ministerio de Agricultura e Cria, Oficina Nacional de Pesca, Caracas.

Moreira Filho, O. and Bertollo, L.A.C. (1990). Uma técnica alternativa para preparações cromossômicas em peixes. III Simpósio de Citogenética Evolutiva e Aplicada de Peixes Neotropicais: 42 (Abstract).

Nelson, J.S. (1994). Fishes of the World. 3rd edn. John Wiley \& Sons Inc., New York.
Pereira, A., Bedó, G. and Pereira, J. (1988). Estudio cromosomico preliminar de Micropogonias furnieri Desmarest, 1823 (Perciformes, Sciaenidae). Bol. Soc. Zool. Uruguay $2^{a}$ epoca 4: 23-26.

Phillips, R.B., Pleyte, K.A. and Hartley, S.E. (1988). Stock-specific differences in the number and chromosome positions of the nucleolar organizer regions in arctic charr (Salvelinus alpinus). Cytogenet. Cell Genet. 48: 9-12.

Ringuelet, R.A., Aramburo, R.H. and Aramburo, A.A. (1967). Los Peces Argentinos de Agua Dulce. Com. Invest. Cient., La Plata.

Rossi, A.R., Gornung, E. and Croseti, D. (1997). Cytogenetic analysis of Liza ramada (Pisces, Perciformes) by different staining techniques and fluorescent in situ hybridization. Heredity 79: 83-87.

Santos, G.M., Jégu, M. and Merona, B. (1984). Catálogo de Peixes Comerciais do Baixo Rio Tocantins; Projeto Tucuruí. Eletronorte/ CNPq/INPA, Manaus.

Soares, L.H. (1978). Revisão taxonômica dos sciaenídeos de água doce da região amazônica brasileira (Osteichthyes, Perciformes, Sciaenidae). Master's thesis, PPG-BTRN, INPA, Manaus.

Sumner, A.T. (1972). A simple technique for demonstrating centromeric heterochromatin. Expl. Cell Res. 75: 304-306.

Tripathi, N.K. and Das, C.C. (1988). Karyotypes of five Indian perciform fishes. Copeia 2: 231-233.

Wang, J., Zhao, X., Wang, X. and Tian, M. (1994). Karyotype analysis for seven species of clupeiform and perciform fishes. Zool. Res. 15: 7679 .

Yu, Z., Kong, X. and Xie, Z. (1996). Studies on the chromosomes of five species of marine fish. J. Ocean Univ. Quingdao 26: 44-48.

(Received February 27, 1998) 